\title{
The Economic Dimensions of Chinese Investments in Africa (2000-2015)
}

\author{
Ayoub Taha Sidahmed \\ Faculty of Economics, Sudan International University, Khartoum, Sudan \\ Email address: \\ ayoubmossawi@yahoo.com

\section{To cite this article:} \\ Ayoub Taha Sidahmed. The Economic Dimensions of Chinese Investments in Africa (2000-2015). International Journal of Business and \\ Economics Research. Vol. 6, No. 6, 2017, pp. 153-161. doi: 10.11648/j.ijber.20170606.12
}

Received: December 3, 2017; Accepted: December 12, 2017; Published: January 18, 2018

\begin{abstract}
This study has been performed on the reality of the economic dimensions of China Investments in Africa during the period between (2000-2015). The Study adopted the descriptive analytical method by standing on the volume and the type of Chinese investments in the African continent. The study focused on the returns of these investment and the related exchange relations, on the economies of the African countries. The study found that the Chinese investments in Africa are direct investments that influenced the size and nature of the exchange between the two parties, which has been in favor of China's balance of trade. The study confirmed the increase of Chinese investments in the continent during the period (2000 -2013) but these investments began to decline thereafter. The study attributed this decline to the slowdown of China economy, instability in different African countries, in addition to the economic pressures exerted by western countries. All this has led to the decline in investments \& exchange with the countries of the continent in general. In addition the study has reported that Chinese investments were concentrated on the field of natural resources and energy, which led to uneven impact on the economic indicators of the continent countries (poverty rates, GDP, growth rate \& balance of trade. est.). In conclusion the study recommended that Chinese investments in Africa should be taken with more studies and analysis \& with some additional control, monitoring and evaluation. Also African countries should re-evaluate their regional economic alliances and entities to avoid contradiction \& lack of coordination in their investments policies, especially when dealing with foreign investments.
\end{abstract}

Keywords: Investment, Natural Resources, Exports, Imports Economies

\section{Introduction}

One of the priorities of the growing Chinese economic ties with African countries in recent years is focusing on opening African markets to Chinese products. This secures its imports of energy and raw materials from these countries. Owing to the importance of this relation and its direct returns on the economic aspects of African countries, this study has been conducted to get a breasted of the economic dimensions of this relation through exploring exchange volume and Chinese investment orientations in all economic fields.

This study has adopted the descriptive analytic methodology to highlight the volume and type of Chinese investments in the continent to eventually arrive at results which support the study's hypotheses, conclusions and recommendations.

\subsection{Statement of the Problem}

Chinese investments relations with African countries display commercial, developmental and economic dimensions, consequently raising the following questions:

* What are the economical dimensions of the Chinese investments in the African continent?

* What sectors are targeted by Chinese investments?

* What countries do Chinese investors focus upon?

\subsection{Hypotheses of the Study}

* Chinese investments in the African countries focus more on the natural resources sectors.

* China's investments, though, steadily increasing has differing impacts upon the economic performance of African countries. 


\subsection{Significance of the Study}

This study tries to reveal the fears related to the increase of Chinese investments in Africa, at the expense of western countries. Some researchers label these investments as domination and exploitation of the abundant natural resources in the black continent. Besides this, the study will provide other researchers with the necessary insight to conduct further related studies.

\subsection{Objectives of the Study}

*To get a breasted of the nature and size of Chinese investments in the African continent.

*To high light the economic strategic nature of these investments.

\subsection{Methodology of the Study}

This study employed the descriptive analytical methodology in describing the nature and volume of trade exchange between china and the African countries during the study period.

\subsection{Scope of the Study}

Time limitation covers the period (2000-2015), where the year 2000 earmarks the beginning of noticeable growth of Chinese investments in Africa.

Place limitation: African continent.

\section{The Theoretical Framework of the Study}

\subsection{The Concept of Foreign Investment}

Foreign investment refers to the type of investment $\mathrm{s}$ where the capital, human resources (both administrative and technical, raw materials finished and semi-finish products together with modern technology are transferred from one country to another. Abu Qahaf A. defined direct investment as that where savings from a rich country flow to another in search for higher profits in an environment characterized by political, economic and institutional stability) ${ }^{1}$. The sum of foreign investment was estimated at 1.5 trillion dollars in 2000 and rose to $1.43,1.23$, \& 1.76 trillion dollars in the years 2013, 2014 and 2015 respectively.

Growing economies, such as that of china, represents half of the top ten beneficiaries from the global direct investment. An UNCTAD report cited that by the end of 2014 china has become No (1) beneficiary from foreign investment in the world excelling the United States.

\subsection{Foreign Investment Theories}

Foreign investment theories have been based upon certain principles to interpret ate foreign investment orientation:

1 Abdelslam Abu Qahaf-economics of investment \& management -Dar Al Marifa Algamia -Egypt 2000-pp 216/217 a. Protection principle: Where foreign countries adopt precautionary measures to secure non-leakage of their technology to host countries.

b. Site principle: Here foreign countries attempt to benefit from raw materials and markets to attain maximum profits versus low production cost.

c. Interest Rates Principle: This is regarded as a direct, effective indicator for the flow of foreign capital.

d. Abundance Principle: this principle states that abundance of raw material attracts foreign investment.

e. Risk distribution principle: Distribution and variation of economic activities lessens the impact of possible risks and accordingly investments are distributed in many countries.

f. Loss compensation principle: Here foreign investments try to compensate for the possible losses in the host country through expanding their investment to other countries.

g. Motivation principle: Thinkers and scholars have adopted this principle to justify the flow of foreign investment to countries.

h. Competitive advantage principle in production cost: Many scholars have advocated the notion of foreign investment. Karr, for example stated that, "foreign investment secures foreign capital, and employment", Stowipher confirmed that "foreign investment helps in capital formation", Dennej followed suit saying that "it helps in exploitation of resources", on the other hand some view foreign investment as exploitation of countries and drainage of their resources while others view it as increase in export and promoting technology.

\subsection{Types of Direct Foreign Investment}

a-In terms of Form:

This is a type of investment seeking a foreign identity already established through possession, transfer of property, merge or buying across border.

b-In Terms of Strategy:

1-Horizontal investment:

It refers to investing in all branches which produce goods similar to those of the mother country to facilitate access of investors to foreign markets or to overcome external factors such as customs' duty barriers or transport cost which might have a negative impact on the competitive status of exports.

2-Vertical investment:

It refers to the investment in the different stages of designing, production and marketing of products in different countries through affiliated companies to benefit from production cost differences in different countries. Vertical investment always embraces activities with value added.

The foreign direct investment is characterized by a dual nature represented by an economic activity conducted by a foreign investor in the host country where he enjoys total or partial ownership of the activity. Projects sprouted from such investments leave an agreed-upon legal dimension defining the relationship between the investor and host country.

In reality, foreign investors favor direct investments as this allows them to invest in the activities which they prefer. Such activities give them more power and control, though the host 
countries may have laws and regulations that govern the directions and of investment in fields which respond to their macro-economic policy.

\subsection{Objectives of Foreign Investment in Developing Countries}

1-Access to raw materials in host countries to meet development needs.

2-Benifiting from exemptions and merits that granted by investment laws in host countries to attract foreign investment.

3-Opening new markets to foreign companies products in host countries.

4-Benefiting from preference merits in host countries as work cost and other production costs are generally low compared with other countries.

5-Foreign companies through their investment try to gain optimum profits compared to what they could have attained in their original homeland.

6-To benefit from advanced technology processed by foreign companies in producing commodities which could easily compete those of the host countries.

7-Attempting to extend their activities to other countries lessens risks involved through distributing these investments in a number of countries. This could explain china's investment in Africa as a whole.

\subsection{The Importance of Foreign Investment to the Host Countries}

1-To benefit from advanced technology possessed by developed countries.

2-Atraction of foreign capital to invest in projects which, will eventually result, in the increase of production and employment opportunities, for the local labor force.

3-Through foreign investment, host countries try to raise export size in an attempt to evade deficit in balance of trade especially through exporting products. This tendency depends on investment laws in the host countries (Tunisia doesn't allow foreign investors to sell most of their products locally) ${ }^{2}$.

4-Securing training opportunities for the local labor force to be able to operate highly sophisticated production machinery.

5-Through foreign investment host countries expand their relations with the outside world and consequently develop and increase trade exchange.

\subsection{Foreign Investment Indicators in Host Countries}

These are the factors which interact to attract or rebel foreign investment, we could review some of the factors as follows:

a. The degree of the stability of the macroeconomic variables, in host countries.

2 Hussen Ali kharbosh -Foreign Investment theory and practice -Zahran for publishing \& distribution -Jordon-Oman 1999-pp 123 b. Access to supporting of financing and banking services.

c. the size of markets in the host countries, which could be attained through estimating the absorptive capacity.

d. Access to the local and regional markets.

e. Efficiency of the basic-infra structure.

f. Relative availability of production elements.

g. Availability of export opportunities.

h. Degree of abundance of natural resources in host countries.

i. Competitive ability of products.

j. Degree of keenness of host countries to apply environmental standards.

The Arab Institution for Investment guarantee has organized these indicators in 5 different groups as follows:-

Group (1): It includes the institutional and economical indicators in the host country (legal, economical conditions).

Group (2): includes the factors related to investment environment (availability of foreign currency, flexibility of communication with investment organs, movement without hindrance in the host country).

Group (3): Include infra-structure and security stability.

Group (4): includes the size of material and moral support on the part of the host country, (size of local market, investment opportunities, and banking facilities).

Group (5): Availability of a data base, cooperation between investment organs (bodies) and stability of investment policies.

From the above review, it is evident that most of the principles upon which investment theories are based coincide with the reality of Chinese investment in Africa.

\subsection{China's Economic Motives in Africa}

(a) Crude oil:

i. China has become an oil importer country as from 1990 (nearly 600,000 barrels per-day) and is expected to rise to more than $(7000,000)$ in $2016^{3}$.

ii. China's oil reserve is limited (suffices for only 21 years as estimated in 1997. $)^{4}$ This means china will remain with no oil reserve by the end of 2018).

iii. Disputes and tensions in the Middle East made china varied its oil reserve supplies.

iiii. The spectacular growth which china has witnessed as from the $90 \mathrm{~s}$ and which was estimated at $10 \%$ and its total dependence upon oil led to china's interest in Africa's oil.

As stated before, the reality supports china's keenness to ensure the continuous flow of the African oil through a strategy based on a number of parameters:-

A-Establishing a number of specific administrative bodies to develop political, economic and cultural relations with African countries and widening the responsibility of already found organs and administrations to include all aspects of joint cooperation.

B-Facilitating the establishment of a number of research

3 Economic forum for Asian \& Pacific Ocean countries-Estimates.

4 Walid Abelhi -the position of China in the internal order (1978-2010)-Emirates center for strategic researches pp 80/81 2000 
centers, and Chinese civil society organizations, e.g. Chinese African cooperation forum initiated by Beijing in 2000, with 46 African member countries. One of its marvelous achievements is the dropping of 1.2 billion dollars of African debts.

There is also Chinese African business council which was founded in November 2004 to promote Chinese private sector invest in the Cameron, Ghana, Mozambique, Nigeria, South Africa and Tanzania. The current trade exchange between china and Africa is 30 billion dollars.

C-The shuttle diplomacy, and the visits that paid by Chinese responsible officials to Africa.

D-The attempts to protect oil wells and natural gas in some African oil countries such as Sudan. There is also Chinese attempt to reach to Guinea Gulf (rich in oil) to compete the USA in oil investments. Practically it has succeeded in laying a footing in Angola, Gabon, Equatorial Guinea, now china imports more than $25 \%$ of oil from Africa and is seeking more oil imports because its oil needs will double in 2030. In addition to Sudan china imports oil from Chad, Algeria, Angola and Gabon (e) there are also attempts for oil contracts in North Africa with countries such as Algeria and Libya.

(b) Mineral Wealth Motivation:

1-Metallic Minerals: There are the minerals that controls and directs a Country's economy and its industrial course. The excel agricultural products in that they could be stored and repeatedly used

(Characterized by flexibility and long use)

(1) Minerals are components of most industrial products, Magnesium for example is essential in alloys antimony is used in plumbing while nickel, for its flexibility, is important in industry. Cobalt is also used in jet locomotives. Iron is indispensable in most industries. Other support energy field (coal and natural gas)

(2) Metals such as diamonds have high monetary value.

To confirm the economic orientation of Chinese investment in Africa, more than 200 companies operate in Sudan in economic, industrial and mining field.

\section{The Practical Side of the Study}

\subsection{The Basics for China's Economic Strategy in Africa}

1-China's policy, contrary to western countries is based on the principle of (non-intervention in the political affairs of African countries and not to impose economical or political conditions upon them such as (freedom and liberation of economy as a prerequisite for development), the relationship is based on interaction and non-domination.

2-China policy in its relation with African countries is more acceptable to Africans, than the western one, the history of western domination during the colonial era made African countries suspicious in their relations with those countries, Also western countries advocate decentralized forms of governments, such tendency contradicts those countries which claim that centralized governments are more suitable for their countries.
3-China's aid to African countries is a mixture of grants and non-profit aids or aids with very low interest.

4-China is interested in Africa as a whole, but tightens its relations with pivotal countries such as Ethiopia in the eastern region, Kenya in the central, South Africa in the south, Egypt in north Africa and Nigeria in west Africa, China's focus in Nigeria the second biggest economy in Africa, where it built railway lines, schools and hospitals together with water resources and communication technology.

Also, in, Kenya, their partnership is consolidated between the two countries leading to China's interest in infrastructure, renewed energy, agriculture and environment protection of games (non-domesticated animals) and tourism.

China cooperates with Africa as a whole through ChineseAfrican cooperation forum, as an institutionalized reference, in addition to bilateral cooperation such as the diplomatic relations forum between china and South Africa and the ambassador level. China has also fulfilled its commitment to consolidate relations with the African union, regional organizations and African institutions, and backed the leading role of the African union in solving African problems, besides china positively participates in the UN peace keeping force in Africa. In addition Chinese investment is not confined to a certain sector but extends to include services, industry agriculture and transport sectors beside oil.

China's keenness to invest is motivated by the fact that its investments haven't been influenced by security and political situations in Africa, China has heavily invested in countries which witnessed instability such as The Democratic Republic of Congo, Eritrea, Guinea, Burundi, Angola and Central Africa (china has a great ability of adaptation without offending this country or that regime $)^{5}$.

\subsection{Assessment of Chinese Investment in Africa}

It is noteworthy that china's investment in the African continent has been mainly directed towards countries rich in natural resources such as Ethiopia, Kenya and Uganda.

Table 1. Estimation of Natural Resources in the African continent.

\begin{tabular}{ll}
\hline Resources & Africa's share \\
\hline $\begin{array}{l}\text { 1-Non-Usedagricultural lands } \\
\text { 2-High productivity agricultural } \\
\text { lands. }\end{array}$ & $\begin{array}{l}60 \% \text { of the global non-used } \\
\text { agricultural land. } \\
8 \% \text { of the continent }\left(23,00000 \mathrm{~km}^{2}\right)\end{array}$ \\
$\begin{array}{l}\text { 3-agricultural lands with good } \\
\text { productivity. }\end{array}$ & $\begin{array}{l}35 \% \text { of the continent } \\
\text { 4-medium productivity }\end{array}$ \\
$\begin{array}{l}\text { agricultural lands. } \\
\text { 5- Low productivity lands } \\
\text { (suitable as pastures). }\end{array}$ & $17 \%$ of the continent \\
6-water resources. & $35 \%$ of the African continent \\
7- animal resources & 5400 billion cubic meters/year \\
\hline
\end{tabular}

Source: Arab Bank for Economic Development in Africa (Gaziera Center for studies)

5 Dr. Yahia Alyahiyawi -China in Africa -Investment perquisites \& exploitation incentives -Algezira studies centre -report series june 2015 
Table 2. Estimation of Mineral Resources (petrol, others)in the African continent.

\begin{tabular}{|c|c|}
\hline Items & Africa's Reserve \\
\hline \multicolumn{2}{|c|}{ Strategic Minerals: } \\
\hline 1-crude oil & $12 \%$ of World Reserve \\
\hline 2-Natural gas & $10 \%$ of World Reserve \\
\hline 3-Antimon & South Africa $(\mathrm{No}(1)$ producer \\
\hline 4-Chrome & $74 \%$ of World Reserve \\
\hline 5-Cobalt & Zaire (Embraces $63 \%$ of World Reserve. \\
\hline \multicolumn{2}{|c|}{ Essential Minerals: } \\
\hline Iron & Mauritaniais the fifth producer globally \\
\hline Brass & Zambia embraces $9 \%$ of the world reserve. \\
\hline \multicolumn{2}{|c|}{ Rare But Essential Minerals: } \\
\hline Aluminum & Guinea possesses $15 \%$ of World Reserve \\
\hline Magnesium & South Africa is the second biggest producer \\
\hline
\end{tabular}

Source: Geography Dept, Babylon University, Iraq (2015).

Table 3. Estimates of Africa's share of world production of some important Minerals.

\begin{tabular}{ll}
\hline Mineral & Share in World in Production \\
\hline Platinum & $80 \%$ \\
Copper & $40 \%$ \\
Gold & $25 \%$ \\
Cobalt & $27 \%$ \\
Iron & $9 \%$ \\
\hline
\end{tabular}

Source: World Bank’s Estimates 2014/2015

(1) These various resources and huge economic potential Africa possesses requires investment to be used for the benefit of its inhabitants. I may assume that China hasn't randomly chosen Africa for its investment but based on a history of good relations that dates back to the middle of the twentieth century.

(2) Chinese investment in Africa has targeted sectors requiring huge capital in countries suffering from shortage in such capital, such as Ethiopia and countries of central and western Africa. This justifies the financing orientation in Africa and to benefit from the competitive advantage of skilled labor force in other countries such as South Africa and some countries in North Africa.

(3) China's investment has taken the direct form; such investment is characterized to be lengthy in time and participation in the capital and administration. Arab institution for the Guarantee of Investments defines it as "long term investment where investors are active participants in administration and decision making through participation in the capital of the investment project."

Also, studies indicate that Chinese investment in the African continent take the form of deals, essentially targeting natural resources. Chinese direct investments in Africa mount to 26 billion dollars by the end of 2013. This figure represents $3 \%$ of foreign investment that same year. UNCTAD's report indicates that (china's investments in the black continent represent $4.5 \%$ of the total direct investment in 2015).

In trade exchange we find African -Chinese investment has steadily increased in recent years. Its investment in infra-structure, construction, oil, agriculture or trade exchange has tremendously spread in Africa as a whole. Also, Chinese cooperation and grants offered to African countries don't represent any political burden or external worry. China has repeatedly declared that its cooperation with Africa is for the benefit of its peoples and doesn't represent any struggle against any international force in search of influence. This tendency is confirmed by the figures and variety of and size of the African Chinese cooperation. African truly prefers cooperation with china not out of fear or poverty: the situation created by the western colonial rule made these countries in bad need for material scientific and technical aid. Figures indicates that Chinese exports to Africa have approximately risen nine times since 2000, though trade between the two parties only represent $4 \%$ of the global trade it remains a significant figure, taking into consideration its quick development (the size of trade exchange amounts to 200 billion American dollars. Also Chinese investment in Africa during 2013 alone exceeded 3 billion dollars and this makes china one of top investment and trade partners in the African continent. $)^{6}$

Table 4. Structure (components of African exports to china 2000-2016).

\begin{tabular}{llll}
\hline Oil and natural sources & Minerals & Food & Finished products \\
\hline $70 \%$ & $15 \%$ & $10 \%$ & $5 \%$ \\
\hline
\end{tabular}

Source: China statistics year book 2015 .

It is evident that China's imports from Africa are confined to oil, minerals and natural resources (abundant in Africa). It represents 855 from the overall import during the study period.

Table 5. Africa's Imports from China.

\begin{tabular}{llll}
\hline $\begin{array}{l}\text { Preparation } \\
\text { materials }\end{array}$ & $\begin{array}{l}\text { Medium } \\
\text { commodities }\end{array}$ & $\begin{array}{l}\text { Consumer } \\
\text { goods }\end{array}$ & $\begin{array}{l}\text { Finished (ready } \\
\text { made) products }\end{array}$ \\
\hline $36 \%$ & $35 \%$ & $20 \%$ & $9 \%$ \\
\hline
\end{tabular}

China statistic year book 2015

Table 4 and 5 indicate that china's imports is concentrated in raw materials (oil, minerals, natural) representing $85 \%$ of its import from Africa, while African imports from China is concentrated in infra-structure commodities such as (preparation materials,, medium commodities) representing $71 \%$ of china's exports to Africa, besides China's great interest in Africa is evident in the great increase in Chinese companies operating in Africa (table below).

Table 6. Number of Chinese companies operating in Africa.

\begin{tabular}{lll}
\hline Period & 2000-2005 & 2006-2015 \\
\hline No. of companies & About 700 companies & More than 2000 companies. \\
\hline
\end{tabular}

Source: $10^{\text {th }}$ Gazeira forum. Chinese African relations.

6 Mahahmoud Iraqi -Africa \& China -partnership \& construction -African research \& studies center Cairo university 2013 


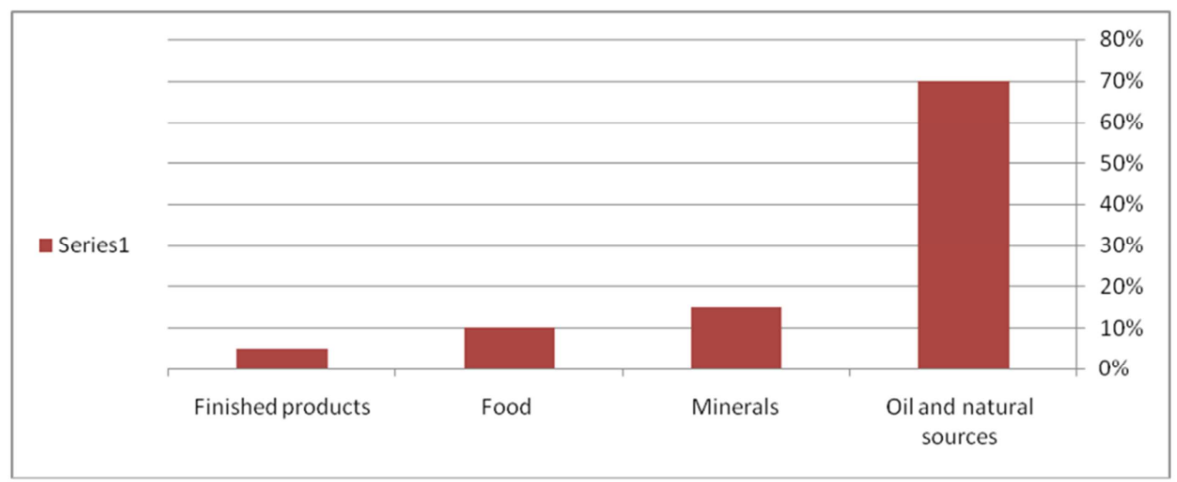

Figure 1. Components Structure of African exports to china

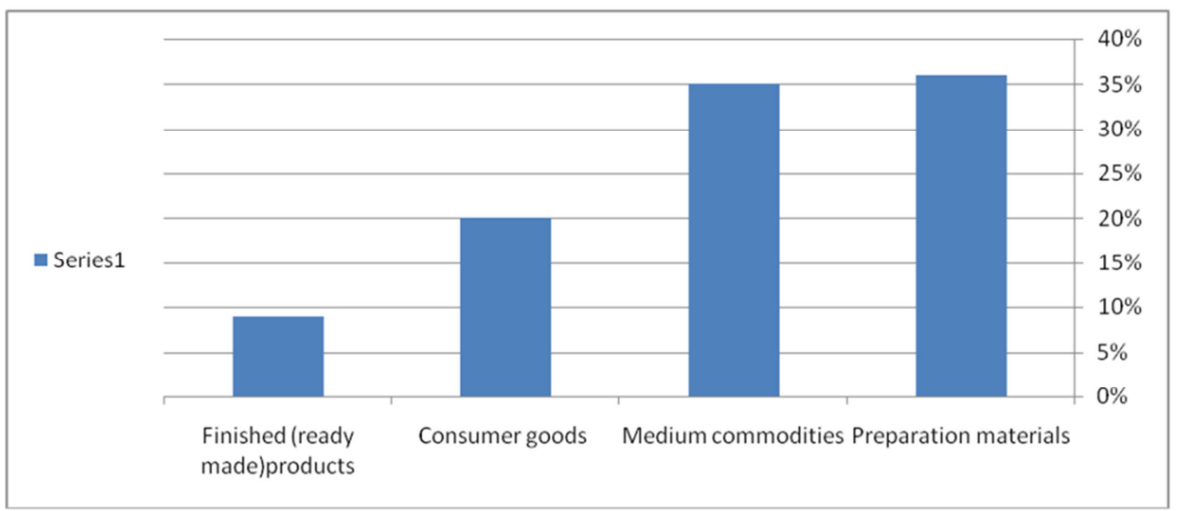

Figure 2. Africa's Imports from China.

There is $186 \%$ increase in the number of Chinese companies operating in Africa distributed in some African countries and active in agriculture, mining, building and construction and industry in addition to logistic support.

All of the above points support the first hypotheses of the study which states that China's investment in Africa is concentrated in natural resources, also table 6 supports the hypotheses as it indicates the increase of Chinese companies operating in Africa and their presence in most African counties and their interests in sectors rich in natural resources.

The Economic Performance of African Countries:

1-According world bank reports, the first decade of the $20^{\text {th }}$ century had witnessed tremendous increase in energy and minerals' prices mounting to $160 \%$, as for precious metals the increase exceeded $300 \%$ where as the increase in agricultural products exceeded $100 \%$, in my opinion the, the increasing China's interest in natural resources was a decisive factor in their price increase.

2-In my opinion, the recession in China's economy, especially in 2015, had a negative impact on a number of African countries, figures indicates that economic growth had declined from $8 \%$ to about $6 \%$. Many attributed the recession to the demand decrease of Chinese products.

Also, the economic policy adopted was directed toward increasing wages, but this policy isn't met by increase in consumption rate, especially in the real-estates field which represents $5 \%$ of the output. This led to an increase in production cost and a sharp decline in its competitive capacity. This situation coincided with the governmental internal and external debts (about 28.2\%) of China's local output.

Also, the exchange rate of Chinese currency (the Yuan) as a result of American pressures, this had a negative influence of the competition states of china's exports compared with these of china's neighboring countries. And as china is the No (1) oil consumer in the world (approximately 7.4 million barrels a day, the Chinese economic recession has to sharp decline in oil prices globally. All this unfavorable situation china had experienced, had negatively influenced Africa's economic indication as we will see in the review below

The economic growth rate:

Some of the African countries south of the Sahara were hard hit by the Chinese economic recession; their economies had recorded a 3.8 decline which was considered the biggest rate since the beginning of the millennium measure by the World Bank indicators. Makinzi institute experts claimed that $25 \%$ of the overall African economy's growth resulted from the Chinese demand increase of the African oil and Minerals.

From the previous review we can assess the impact of Chinese investment upon the African economic performance as displayed in the tables below: 
Table 7. Increase Rate in the overall domestic out put.

\begin{tabular}{llllllll}
\hline Year & $\mathbf{2 0 0 9}$ & $\mathbf{2 0 1 0}$ & $\mathbf{2 0 1 1}$ & $\mathbf{2 0 1 2}$ & $\mathbf{2 0 1 3}$ & $\mathbf{2 0 1 4}$ & $\mathbf{2 0 1 5}$ \\
\hline Overall local out put & 2.3 & 4.7 & 0.8 & 5.6 & 3.5 & 3.5 & 2.6 \\
\hline
\end{tabular}

Source: economic summary, World Bank, 2015.

Table 7 displays the fluctuating rate in the overall economic output despite the remarkable rise in 2010 and 2012, but the rate again exhibited its lowest decline by the end of 2015. This may be due to the state of instability which prevailed in the period.

Table 8. Volume of trade exchange between china and Africa (in billions of dollars).

\begin{tabular}{llllllll}
\hline Year & $\mathbf{2 0 0 0}$ & $\mathbf{2 0 0 9}$ & $\mathbf{2 0 1 0}$ & $\mathbf{2 0 1 1}$ & $\mathbf{2 0 1 2}$ & $\mathbf{2 0 1 3}$ & $\mathbf{2 0 1 5}$ \\
\hline Volume of exchange & 10.6 & 106.8 & 150 & 166.3 & 198.5 & 200 & 200 \\
\hline
\end{tabular}

Source: UN investment report.2015

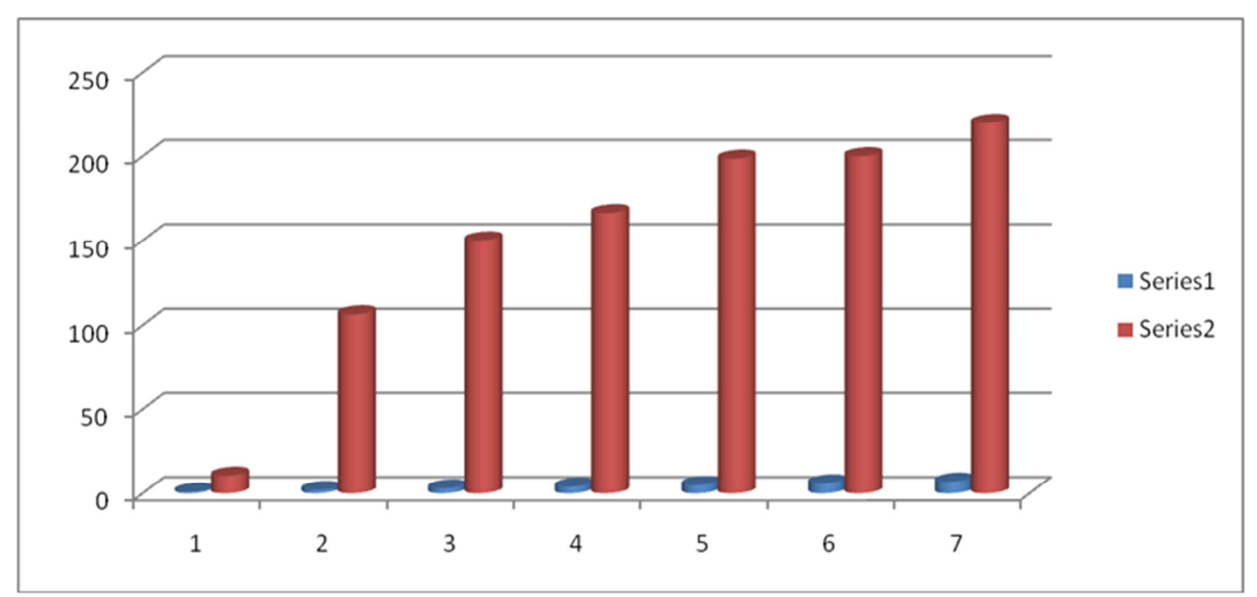

Figure 3.

One could notice that the trade exchange rate between china and Africa has risen to $177 \%$ in the period $2000-2012$ with a yearly average rate $14.8 \%$ while the increase for the period between (2012-2015) only $0.008 \%$ only with percentage average $0003 \%$ per-year approximately. This shows that the exchange after reaching the climax has come to a halt. I hope that the unfavorable status of Chinese economy as a result of western pressures, and the situation prevailing in the African continent shouldn't represent the lost recede in trade exchange between the two parties.

Trade Balance between China and Africa:

Table 9. Volume of exports and imports between China and Africa.

\begin{tabular}{ll}
\hline Continent & $\mathbf{2 0 0 0 - 2 0 1 5}$ \\
\hline Africa's exports to china & Rose from 3.8 to $18 \%$ \\
Africa's imports from China & Rose from $3.9 \%$ to nearly $14.2 \%$ \\
\hline
\end{tabular}

Source: $10^{\text {th }}$ Gaziera Forum: Chinese African relations 2016.
The previous table generally reveals that Africa's exports to China are on the increase. This in my opinion should be interpreted that the trade balance is in favor of Africa African countries exhibit differences in their trade balance in 2007, the trade balance was in favor of Sudan it shifted to China's side (Economic review ministry of finance Sudan since 2007).

Table 10. Trade Quotas: China VS Africa.

\begin{tabular}{ll}
\hline Country $\backslash$ period & $\mathbf{2 0 0 0 - 2 0 1 5}$ \\
\hline Africa's quota in China's foreign trade & Rose from $2.2 \%$ to $56 \%$ \\
China's quota in Africa's foreign trade & Rose from 3.8 to $17 \%$ \\
\hline
\end{tabular}

Source: the $10^{\text {Th }}$ Gaziera Forum, Africa China's relations 2016.

In trade, figures in the above tables 8 and 9 indicate that China is more important to Africa than China is to Africa.

Table 11. Poverty Rate: East Asia VS Africa.

\begin{tabular}{lllll}
\hline Period & East Asia in 1990 & Africa (south of Sahara)1990 & East Asia 2015 & Africa(s. sahara in 2015) \\
\hline Poverty rate & $50 \%$ of the world poor & $15 \%$ of the world's poor & $12 \%$ & $50 \%$ \\
\hline
\end{tabular}

Source: World Bank Report Oct 2015.

The above table indicates that poverty rate in African countries (south of the Sahara) increased tremendously in 2015. Poverty rate in early 90s in E. Asia equals that of 2015 in African countries. World Bank reported that in all regions has witnessed a recede in recent years but gravely extended in countries which depend heavily on exporting raw material or those which has experienced prolonged disputes.

The economic performance indicators in African countries 
which had access to, need further investigation and research because they were the outcome of various and entangled factors. But what is evident is that countries rich in natural resources haven't attained maximum benefits from them to promote development programs.

In a paper presented by Rick Vandier and Tony Pineapples with the title (How Developing countries Rich in Natural Resources Should Harness the Revenues for Growth) published in the Economic Journal (The Royal Economic Association) United Kingdom in March 2011. Cited (developing countries rich in natural resources should employ the revenues in improving wages and increasing investment in both public and private sectors to promote economic growth. The two researchers don't advocate use of these revenues to build reserves of foreign assets for the benefit of future generations. The researchers noticed that countries rich in natural resources such as petrol have generally exhibited low economic performance in comparison to the countries poor in natural resources. The researchers attribute this to a number of factors, in appropriate exploitation of these revenues, increase of savings at the expense of investments, instability of prices or disputes instigated by these revenues.

Table 12. The nature of African Exports 2000-2015 (Sudan as example).

\begin{tabular}{|c|c|c|c|c|c|c|c|c|c|c|c|c|c|c|}
\hline 2015 & 2014 & 2011 & 2010 & 2009 & 2008 & 2007 & 2006 & 2005 & 2004 & 2003 & 2002 & 2001 & 2000 & Year/item \\
\hline $20 \%$ & $31 \%$ & $76.1 \%$ & $85 \%$ & $87.7 \%$ & $95.1 \%$ & $95 \%$ & $90 \%$ & $86.6 \%$ & $82.1 \%$ & $80.5 \%$ & $77.5 \%$ & $81 \%$ & $77.5 \%$ & OIL \\
\hline $49.6 \%$ & $34.1 \%$ & $7.1 \%$ & $3.3 \%$ & $5.1 \%$ & $3.2 \%$ & $4 \%$ & $8 \%$ & $10.1 \%$ & $13.7 \%$ & $15.3 \%$ & $17.9 \%$ & $14 \%$ & $17.9 \%$ & Agri+Animal \\
\hline $28.7 \%$ & $28.7 \%$ & $15.1 \%$ & $9.1 \%$ & $5 \%$ & $1.1 \%$ & $0.8 \%$ & $1.3 \%$ & $1.3 \%$ & $2.3 \%$ & $2.3 \%$ & $2.7 \%$ & $2.7 \%$ & $2.7 \%$ & Mineral \\
\hline
\end{tabular}

Source: Economic Review, Ministry of Finance.

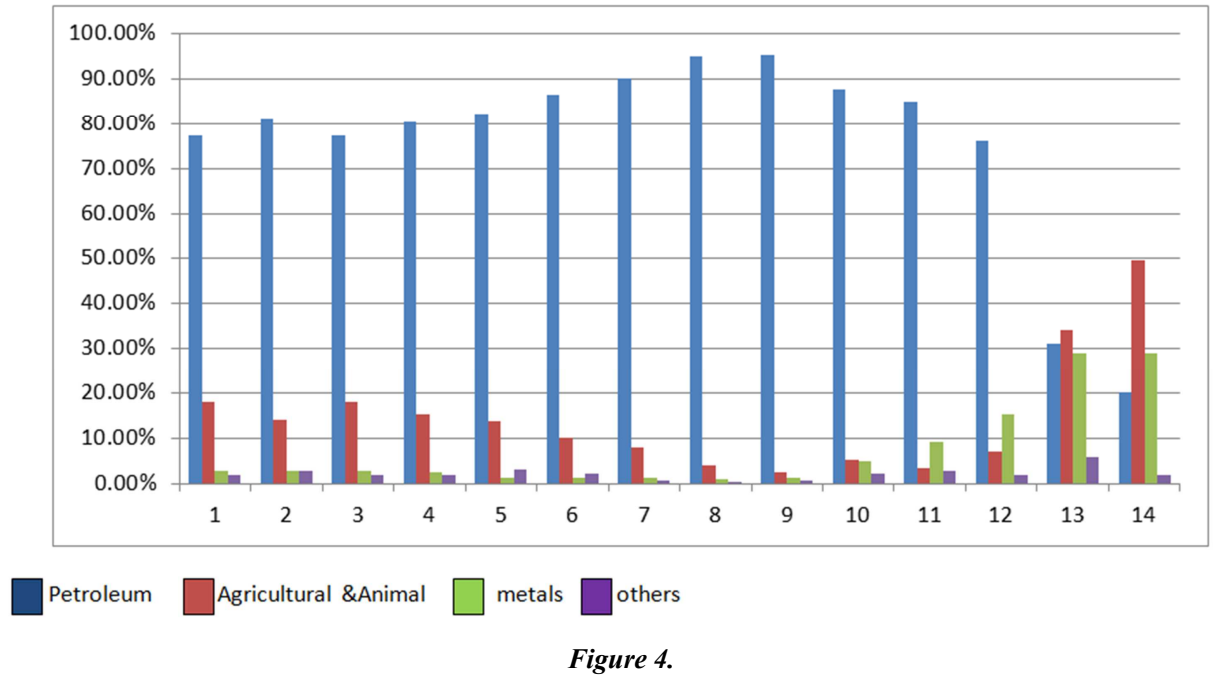

It is noticed that Sudan exports between 2000-2015 was mainly concentrated on raw materials (oil, minerals, agric, animal products) with an approximate average rate of $85 \%$ of all Sudan's exports. It is also noticed that agricultural and mineral exports have tremendously increased as from 2011 to compensate for the great decline in oil exports. This explains the reciprocal tendency in trade relations between the host countries and the investing ones which the following figures below confirm.

Table 13. China's share in Sudan's exports (According to the geographical distribution of exports (2000-2015).

\begin{tabular}{lllllllllllllll}
\hline $\mathbf{2 0 1 5}$ & $\mathbf{2 0 1 4}$ & $\mathbf{2 0 1 1}$ & $\mathbf{2 0 1 0}$ & $\mathbf{2 0 0 9}$ & $\mathbf{2 0 0 8}$ & $\mathbf{2 0 0 7}$ & $\mathbf{2 0 0 6}$ & $\mathbf{2 0 0 5}$ & $\mathbf{2 0 0 4}$ & $\mathbf{2 0 0 3}$ & $\mathbf{2 0 0 2}$ & $\mathbf{2 0 0 1}$ & $\mathbf{2 0 0 0}$ & Years \\
\hline 61 & 63 & 65.6 & 72.5 & 75.8 & 75 & 82 & 75 & 71 & 66.9 & 69.3 & 65.7 & 58.9 & 65.7 & $\%$ China \\
\hline
\end{tabular}

Source: Economic Review Ministry of Finance.

From the above table china still dominate the export of the country.

However, there are numerous positive aspects for the benefit of a number of African countries. For example, in the context of the western boycott to Sudan, the greater petroleum company was founded. It consists of (the Sudanese national oil corporation), (The Chinese National Oil Company), (PETRONAS, Malaysia), (The Indian oil and Natural gas corporation 25\%). The Nile oil company was able to produce and export oil for the first time in 1999 which led to an increase in Sudan's hard currency resources and reflected positively in Sudan's trade balance. Besides more than 200 companies are operating in various fields, such as infra-structure projects, agriculture, industry and services).

As for loans, subsidies, grants and projects China's contribution is remarkable.

For example Sudan came across the following facts and figures. 
Table 14. China's loans to Sudan.

\begin{tabular}{ll}
\hline Years & Million dollars \\
\hline $1970-1979$ & 25.1 \\
$1980-1989$ & 71.0 \\
$1990-2008$ & 3737. \\
Total & 3833.1 \\
\hline
\end{tabular}

Source: Ministry of Finance and Economic planning, Sudan.

Table 15. Grants (2008).

\begin{tabular}{lll}
\hline Year & $\begin{array}{l}\text { Grant Amount } \\
\text { (million dollars) }\end{array}$ & Projects \\
\hline 2008 & 132.2 & Rehabilitation of Blue Nile Bridge \\
2011 & 111 & Food Grants $\backslash$ Humanitarian aid \\
\hline
\end{tabular}

Source: Ministry of Finance and Economic planning, Sudan.

Table 16. Non- interest loans-project.

\begin{tabular}{ll}
\hline Amount & Projects \\
\hline 89 million dollars & $\begin{array}{l}\text { Roads, minor industries, vocational training centers, } \\
\text { rural electricity (generators). }\end{array}$ \\
\hline
\end{tabular}

Source: Ministry of Finance and Economic planning, Sudan.

Table 17. Low financing cost aids.

\begin{tabular}{lll}
\hline Year & Amount (million dollars) & Field (according to terms) \\
\hline 1996 & 17.6 & Gold and petrol excavations \\
1999 & 12 & Fishing resources (red sea \\
& 12.1 & Khartoum electricity \\
2006 & 19.5 & Electricity (capital \\
2008 & 3833.2 & Development loans \\
2009 & 6.3 & Different \\
2010 & 8.6 & Different \\
& 10 & Crude Oil, water, Electicity, \\
2011 & 740 & Roads, Bridges \& \\
& 13 Billion dollars & communications \\
2015 & & Crude oil \\
\hline
\end{tabular}

Source: Ministry of Finance and Economic planning, Sudan.

China found the Chinese African development fund with a budget estimated at 5 billion dollars supported by a package of programs till 2015.

Table 18. African projects receiving Chinese aid till 2015.

\begin{tabular}{ll}
\hline Item & Nature of projects \\
\hline $\begin{array}{l}\text { Training of human } \\
\text { resources }\end{array}$ & China trained 11000 officials and technicians \\
Hospitals & China equipped more than 50 hospitals, plus \\
Vital utilities & 33 centers for malaria treatment \\
Railways & 375 social utility plus 144 economic utility \\
& China built and rehabilitated railway lines in \\
\hline
\end{tabular}

Ministry of Finance \& Economic planning

\section{Results and Recommendations}

\subsection{Results}

From the above review I can conclude that:

1. Most of the principles upon which foreign investment theories are based coincide with the realities of Chinese investment in Africa and that Chinese investments are direct ones targeting mainly natural resources sectors.

2. Chinese investments in the African continent though steadily increasing, have differing impacts upon the economic performance of African countries. This could be attributed to western pressures exerted upon china together with poor performance exhibited by Chinese economy in recent years and the state of instability which bit most of the African continent recently.

\subsection{Recommendations}

The study recommends the following:

1-The necessity of conducting further researches on foreign investment with appropriate analysis, monitoring and evaluation.

2-African countries should re-evaluate their regional economic alliances and entities to avoid contradictions, lack of coordination, as regards to foreign investment.

3-African countries should coordinate their investment policies, taking into consideration the priorities of each country to obtain maximum benefits.

\section{References}

[1] Abdelslam Abu Qahaf-economics of investment \& management -Dar Al Marifa Algamia -Egypt 2000.

[2] Hussen Ali kharbosh -Foreign Investment theory and practice -Zahran for publishing \& distribution -Jordon-Oman 1999.

[3] Walid Abelhi -the position of China in the internal order (1978-2010)-Emirates center for strategic researches pp $80 / 812000$.

[4] Mahahmoud Iraqi -Africa \& China -partnership \& construction -African research \& studies center Cairo university 2013.

[5] Dr. Yahia Alyahiyawi -China in Africa -Investment perquisites \& exploitation incentives -Algezira studies centre -report series june 2015.

[6] Falah Khalaf Arobi -conept of investment Env-Ahwear Almutamdin.

[7] Economic forum for Asian \& Pacific Ocean countries Estimates.

[8] World Bank's Estimates 2014/2015.

[9] Economic Review Ministry of Finance \& Economic planning.

[10] China Statistics yearbook 2015.

[11] University of Babel-E. G S -Iraq 2015.

[12] UN investment report 2015.

[13] Agezira -tenthforum (China-Africa relations - 2016).

[14] Arab Bank for economic Development in Africa.

[15] Economic Summary WB 2015. 